\title{
Forvaring i Norge, Danmark og Grønland - noen likheter og ulikheter
}

\author{
Av Berit Johnsen og Hans Jørgen Engbo ${ }^{1}$
}

\begin{abstract}
A comparative study of preventive detention in Norway, Denmark and Greenland reveals both similarities and dissimilarities in the organisation of this criminal sanction. By examining legislation and practice and interpreting this in relation to the overall context of criminal justice, the paper seeks to identify similarities and dissimilarities in the three countries. The study shows that the legal circumstances required for a sentence of preventive detention are similar in all three nations. Nonetheless, there are considerable differences in the extent to which preventive detention is used. These differences reflect differences in the status the sanction holds in each country. While the type of crimes that lead to preventive detention are quite similar, there are substantial differences in how long offenders are kept in preventive detention and how the process towards release is organised. While the arrangement of preventive detention in Denmark and Greenland is quite easily adjustable to the prevailing sense of public justice, the Norwegian arrangement seems to put more weight on ensuring the legal protection of offenders. The context of interpretation is decisive for what is considered advantageous or not in the organisation of preventive detention in the three countries.
\end{abstract}

\section{Indledning $^{2}$}

Ved reformer av strafferettssystemene i de nordiske land er det en tradisjon å se hen til de ulike landenes systemer. Slik har det også vært for reformer av det danske forvaringsinstituttet og det norske sikringssystemet, hvor det har vært en gjensidig påvirkning i utarbeidelsene av de eksisterende forvaringsordningene $\mathrm{i}$ Danmark og Norge. ${ }^{3}$ Samtidig har det grønlandske forvaringsinstituttet også en del likheter og ulikheter både med det danske og det norske. Våre erfaringer gjennom ledelse av danske og grønlandske institusjoner med forvaringsdømte og forskning om forvaring, tilsier at det både er likheter og forskjeller i våre lands

* Title in English: Preventive Detention in Norway, Denmark and Greenland: Similarities and Dissimilarities. 
forvaringsinstitutter. Det er nysgjerrigheten på likhetene og forskjellene som danner bakgrunnen og er drivkraften i denne studien.

I studier der man sammenligner ulike lands rettssystemer (komparative studier) ligger det elementer av forståelse - hvordan forstå likheter og forskjeller og læring - hvordan lære av hverandres systemer. ${ }^{4}$ Det er ingen bestemt metode knyttet til slike studier, men ofte tilstrebes et mest mulig helhetlig perspektiv for å synliggjøre sammenhenger. Det betyr at flere områder - som kunne vært utgangspunkt for egne studier - berøres uten å gå i dybden. ${ }^{5}$ Slik er det også her, vi berører en rekke problemområder som kunne vært interessante for særegne studier. Foruten skriftlig kildemateriale har vi innhentet data gjennom studiebesøk i Danmark og Norge og intervjuer/samtaler med sentrale aktører som fengselsledere, riksadvokat, og behandlere.

Vi starter med et tilbakeblikk på tidligere lovgivning og aktuelle reformer, for deretter se på lovtekstene om forvaring. Dernest presenterer vi hvor mange som dømmes til forvaring og drøfter rettspraksis. Videre fokuserer vi på gjennomføringen/fullbyrdelsen av forvaringsreaksjonen og progresjon i soningsforløpet, for deretter å ta for oss løslatelse/udskrivning fra forvaring. Avslutningsvis forsøker vi å trekke noen store linjer og sette søkelys på noen dilemmaer.

\section{Et historisk tilbakeblikk}

Etter en reform av sikringsinstituttet ble forvaring i Norge innført 1.1.2002 som én av tre tidsubestemte særreaksjoner med formål om samfunnsbeskyttelse. ${ }^{6}$ Forvaring som betegnelse for en tidsubestemt reaksjon er imidlertid ikke ny, den har eksistert i lovverket siden innføring av gjeldende straffelov i 1902. Etter en revidering i 1929, ble forvaring forholdsvis mye brukt overfor tilregnelige lovbrytere med tilbakefallsfare - fortrinnsvis for vinningskriminalitet - men bruken avtok, og bestemmelsen var ikke i bruk etter 1963. Sikring ble idømt lovbrytere som ble ansett for å ha «mangelfullt utviklede eller varige svekkede sjelsevner». Tilregnelige lovbrytere ble idømt ubetinget fengsel og sikring for inntil ti år (det dobbeltsporede system), og sikringen kunne forlenges av retten.

Prosessen mot reformen i 2002 har vært lang. Den første utredningen forelå i $1974,{ }^{7}$ men pga. omfattende kritikk valgte man å la forslaget bero. Behovet for en forvaringsordning ble imidlertid konstatert etter opphevelse av livstidsstraffen i $1981,{ }^{8}$ og en ny utredning forelå i 1990. ${ }^{9}$ På bakgrunn av denne ble det utarbeidet et lovforslag. ${ }^{10}$ Ved ikrafttredelse av ny straffelov (fra 2005) utelates forvaring fra særreaksjonsbegrepet. ${ }^{11}$

I dansk ret blev forvaring i den nuværende form indført i 1973 som led i en omfattende reform af straffelovens sanktionssystem. ${ }^{12}$ Indtil da havde straffelo- 
ven siden sin ikrafttræden i 1933 opereret med to former for tidsubestemt forvaring, nemlig psykopatforvaring for personer, som ansås som uegnede til påvirkning gennem straf på grund af en «ved mangelfuld udvikling, svækkelse eller forstyrrelse af sjælsevnerne, herunder seksuel abnormitet, betinget varigere tilstand», der ikke kunne karakteriseres som sindssygdom eller åndssvaghed i højere grad, ${ }^{13}$ og sikkerhedsforvaring for professionelt prægede (berigelses)forbrydere, der frembød virkelig fare for samfundets sikkerhed. ${ }^{14}$

Ved reformen i 1973 blev disse former for forvaring afskaffet, og samtidig indførte man den nu eksisterende tidsubestemte foranstaltning for farlige personer og genbrugte hertil betegnelsen forvaring. En mindre justering af betingelserne for idømmelse af forvaring blev gennemført i 1997 som led i en samlet reform med sigte på en forstærket indsats mod seksualforbrydelser.

Grønland fikk forvaring i den nuværende form indføjet i kriminalloven i 1978 (ikrafttræden 1979). ${ }^{15}$ Betegnelsen var dengang anstaltsanbringelse på ubestemt tid, men ved en større lovrevision i 2008 (ikrafttræden 2010) blev foranstaltningen omdøbt til forvaring. ${ }^{16}$ I den oprindelig lov fra 1954 var betegnelsen forvaring brugt om en særlig foranstaltning, som kunne idømmes «lovovertrædere, der må betegnes som erhvervs- eller vanemæssige eller særlig farlige forbrydere, når hensynet til samfundets sikkerhed gør det påkrævet». Det var Grønlands eneste egentlig frihedsberøvende foranstaltning, men i praksis blev den ofte fuldbyrdet under ganske frie forhold eller i et såkaldt forvaringshjem i Nuuk.

Lovrevisjoner/-endringer ser ut til å falle på ganske like tidspunkt for Norge, Danmark og Grønland. I Norge har lovreformene blitt gjennomført i tider der fokuset på samfunnsvern og uskadeliggjøring har vært sentralt. Det er grunn til å tro at dette også er tilfellet i Danmark, og i senere tid også Grønland, og at reformene er knyttet til en samfunnsutvikling og et kriminalpolitisk klima påvirket av internasjonalt rådende diskurser. ${ }^{17}$ Man skal merke seg at kritikken mot tidsubestemte straffer var like sterk i Danmark som i Norge på begynnelsen av 1970-tallet, og ved lovreformen i 1973 ble bruken av tidsubestemte anstaltanbringelser vesentlig innskrenket. ${ }^{18}$ I begge land avtok bruken av tidsubestemte straffer for vinningskriminalitet i tråd med fremveksten av velferdssamfunnet. Mest sannsynlig handler dette om utvikling av ordninger for å erstatte tapte eiendeler, og en reduksjon i behovet for beskyttelse mot slik kriminalitet.

\section{Betingelserne for dom til forvaring}

Mens forvaring i Norge defineres som straff, betegnes forvaring i den danske straffelov som en «foranstaltning» som principielt har forebyggende og ikke straffende karakter. Selv om man taler om en foranstaltning, er ingen i tvivl om, 
at der også ligger en god portion pønale undertoner bag en forvaringsdom. ${ }^{19}$ Den grønlandske kriminallov opererer slet ikke med begrebet straf; alle kriminalretlige reaktioner, inklusive forvaring, betegnes foranstaltninger.

I Norge er vilkåret for å bli idømt forvaring etter straffeloven $\S 39 \mathrm{c}$ at lovbryteren finnes skyldig i å ha begått (forsøkt å begå) en alvorlig forbrytelse - voldsforbrytelse, seksualforbrytelse, frihetsberøvelse, ildspåsettelse eller en annen alvorlig forbrytelse - som har krenket andres liv, helse eller frihet, eller utsatt disse rettsgodene for fare. I tillegg må det antas å være en ncerliggende fare for at lovbryteren på nytt vil begå en slik forbrytelse. Forvaring kan også idømmes for mindre alvorlige forbrytelser av samme art, men da må lovbryteren tidligere ha begått (forsøkt å begå) en lignende forbrytelse, og det må antas å være en sammenheng mellom den nåværende og den tidligere forbrytelsen. Ved mindre alvorlige forbrytelser må gjentakelsesfaren være særlig nœrliggende. Forvaring kan idømmes i stedet for fengselsstraff når en tidsbestemt straff ikke anses å gi tilstrekkelig samfunnsvern.

I Danmark forudsætter en dom til forvaring efter straffelovens $\S 70$, at tre krav skal være opfyldt:

1) Den tiltalte skal findes skyldig i drab, røveri, alvorlig voldsforbrydelse, alvorligere trusler, brandstiftelse eller voldtægt eller anden alvorlig seksualforbrydelse eller i forsøg på en af de nævnte forbrydelser (kriminalitetskravet).

2) Den tiltalte skal antages at frembyde nærliggende fare for andres liv, legeme, helbred eller frihed. Antagelse skal baseres på karakteren af det begåede forhold og oplysningerne om lovbryterens person, herunder navnlig om tidligere kriminalitet (farlighedskravet).

3) Anvendelse af forvaring i stedet for fængsel skal findes påkrævet for at forebygge denne fare (nødvendighedskravet).

De samme kravene skal være oppfylt for en dom til forvaring etter den grønlandske kriminallov $\S 161$. Mens den grønlandske kriminallov også setter betingelser om nærliggende fare for voldtægt eller anden alvorlig seksualforbrydelse, er betingelserne for idømmelse av forvaring for seksualforbrydelser en anelse lempeligere i Danmark. For å idømme forvaring for disse forbrytelsene skal faren være «væsentlig», som er et bredere begreb end «nærliggende», samtidig med at der ved udeladelse af ordet «navnlig» - skal lægges mindre vægt på tidligere kriminalitet. $^{20}$

Selv om lovtekstene er forskjellige i Norge, Danmark og Grønland, er vilkårene for idømmelse av forvaring like. Kriminalitetskravet innebærer at det skal 
foreligge et lovbrudd som har krenket fundamentale rettsgoder, farlighetskravet innebærer en antagelse om en betydelig risiko for at rettsgodene på nytt kan bli krenket, og nødvendighetskravet tilsier at det er nødvendig å verne samfunnet for denne fare. Mens den danske og grønlandske bestemmelsen er uttømmende på kriminalitetskravet og kun omhandler alvorlige, personfarlige lovbrudd, åpner den norske bestemmelsen opp for andre forbrytelser enn de som er nevnt i lovteksten, samt at forvaring kan idømmes også for mindre alvorlige lovbrudd. Begrepet «nærliggende fare» benyttes for å konkretisere farlighetskravet i alle tre land, men mens kravet skjerpes i Norge ved mindre alvorlige forbrytelser, lempes kravet for seksualforbrytelser i Danmark.

Ifølge den norske lovteksten skal det ved gjentakelsesvurderingen legges vekt på den begåtte forbrytelsen (forsøket), sammenholdt særlig med lovbryterens atferd og sosiale og personlige funksjonsevne. ${ }^{21}$ Det skal før en forvaringsdom avsies foretas personundersøkelse av den siktede, men retten kan i stedet beslutte at den siktede skal underkastes rettspsykiatrisk undersøkelse, og dette blir gjort i de fleste sakene. ${ }^{22}$ Forarbeidene legger til grunn at en «tilbakefallsforbryter til voldskriminalitet vil være en karakteravviker», og forvaringsdømte har ofte fătt én eller flere diagnoser. ${ }^{23}$

Forarbejderne til 1973-reformen i Danmark nævner, at der i bestemmelsen ikke er optaget nogen psykiatrisk karakteristik af lovovertræderen, men at det dog må antages, at forvaring i det væsentlige vil finde anvendelse over for personer, som er præget af udtalte karaktermæssige afvigelser. ${ }^{24}$ I Norge og Danmark forutsatte man altså at de forvarede ville være «karakteravvikere», og dette kan leses ut fra vurderingene som gjøres av forvarede. «Karakteravviket» forstås bl.a. ut fra diagnostiseringer av de forvarede som kobles til farlighetskriteriet - dvs. risikovurderinger som inngår i bedømmelsen av graden av tilbakefallsfare. I Grønland kan en gerningsperson på grund af psykisk afvigelse (dog ikke sindssyg eller i en tilstand, der ganske må ligestilles hermed, eller mentalt retarderet på tidspunktet for lovovertredelsen) dømmes til anbringelse på ubestemt tid i en psykiatrisk ledet anstalt i Danmark (dvs. Anstalten i Herstedvester), når vedkommende anses for uegnet til anbringelse i anstalt i Grønland eller en sådan anbringelse ikke giver tilstrekkelig sikkerhed. ${ }^{25}$

En forvaringsdom er tidsubestemt $\mathrm{i}$ alle tre land. I Norge skal retten ved avsigelse av en forvaringsdom utmåle en tidsramme som vanligvis ikke bør overstige 15 år, og ikke kan overstige 21 år, eller 30 år for forbrytelser med strafferamme på fengsel inntil 30 år (f.eks. alvorlige terrorforbrytelser jf. strl. 147a). Tidsrammen kan forlenges med inntil fem år om gangen. ${ }^{26}$ I tillegg bør retten ilegge en minstetid som ikke må overskride ti år. Ved idømmelse av tidsramme på over 15 
år, kan det likevel fastsettes en minstetid som ikke kan overskride 14 år. Når tidsrammen overstiger 21 år, kan ikke minstetiden overstige 20 år. ${ }^{27}$

Minstetiden skal sikre at den forvaringsdømte ikke løslates for tidlig av hensyn til den allmenne rettsoppfatning. ${ }^{28}$ Hvis retten ikke setter en minstetid kan prøveløslatelse vurderes ett år etter at dommen er rettskraftig. Rettspraksis viser en ren straffeutmåling i forvaringssakene, der tidsrammen blir satt lik en alternativ tidsbestemt straff, mens minstetiden blir satt til $2 / 3$ av denne, dvs. ved mulig prøveløslatelse fra en tidsbestemt straff. ${ }^{29}$

En dom til forvaring i Danmark eller Grønland indeholder ikke bestemmelser om foranstaltningens varighed. En forvaringsdømt kan rent teoretisk udskrives/løslades på prøve, efter ganske kort tids afsoning, hvis der allerede på dette tidspunkt er sikkert grundlag for at antage, at den forvarede ikke længere frembyder væsentlig eller nærliggende fare. I Danmark og Grønland har anklagemyndigheden (henholdsvis statsadvokaten og rigsadvokaten) væsentlig indflydelse på fuldbyrdelsesforløbet i forvaringssager. Efter loven påhviler det anklagemyndigheden at påse, at en forvaringsdom ikke opretholdes i længere tid og videre omfang end nødvendigt. ${ }^{30}$ I praksis ser anklagemyndigheden det uden tvivl (også) som sin opgave at påse, at der ikke sker lempelser i fuldbyrdelsen i et tempo, som antages at stride mod den almindelige (pønale) retsfølelse, og anklagemyndigheden bliver i alle forvaringssager involveret i sagsbehandlingen om sådanne lempelser (udgang mm.).

\section{Faktisk brug af forvaring og rettspraksis}

Fra 1.1.2002 til 5.1.2015 er det registrert 224 forvaringsdommer i Norge. ${ }^{31}$ Ser man bort fra konverteringsdommene (sikringsdommer omgjort til forvaring) er det i denne perioden avsagt mellom 8 og 19 forvaringsdommer i året. Antall forvaringsdomme i Danmark har i en årrække ligget ret konstant på 2-3 domme årligt, og 69 personer er dømt til forvaring i perioden 1990-2011. ${ }^{32}$ Tabell 1 viser prosentvis fordeling av forvaringsdommene sett i forhold til lovbrudd.

Tabell 1: Forvaringsdommer fordelt på lovbrudd (i prosent $)^{33}$

\begin{tabular}{|l|c|c|c|c|c|c|}
\hline & Drap & $\begin{array}{c}\text { Ran/ } \\
\text { røveri }\end{array}$ & $\begin{array}{c}\text { Frihets- } \\
\text { berøvelse }\end{array}$ & $\begin{array}{c}\text { Vold } \\
\text { og/eller } \\
\text { trusler }\end{array}$ & $\begin{array}{c}\text { Brann- } \\
\text { stiftelse }\end{array}$ & $\begin{array}{c}\text { Seksual- } \\
\text { lovbrudd }\end{array}$ \\
\hline $\begin{array}{l}\text { Norge } \\
2002-2015\end{array}$ & $24 \%$ & $5 \%$ & $1 \%$ & $15 \%$ & $6 \%$ & $49 \%$ \\
\hline $\begin{array}{l}\text { Danmark } \\
1990-2011\end{array}$ & $12 \%$ & $4 \%$ & $3 \%$ & $25 \%$ & $7 \%$ & $49 \%$ \\
\hline
\end{tabular}


Fordelingen er ganske lik i både Danmark og Norge, og i begge landene er nesten halvparten av dommene idømt for seksuallovbrudd. I Norge er det nest flest drapsdommer, mens det i Danmark er nest flest dommer for vold/trusler. I Danmark er flere dømt for brannstiftelse enn røveri og frihetsberøvelse. I Norge er nesten like mange dømt for ran og brannstiftelse, mens færrest er dømt for frihetsberøvelse. I et sammenligningsperspektiv er likheten i fordelingen av lovbruddskategoriene også interessant sett ut fra forskjellen i hvordan lovverkene definerer hvilke lovbrudd som kan gi forvaringsstraff (ikke uttømmende i Norge).

Det avsies atskillig flere forvaringsdommer per år i Norge enn i Danmark. Siden den norske lovgivningen også åpner for idømmelse av forvaring ved mindre alvorlige lovbrudd, skulle man tro dette forårsaker flere forvaringsdømte. Dette forholdet har imidlertid liten betydning, fordi forholdsvis få idømmes forvaring for mindre alvorlige lovbrudd. ${ }^{34}$

I Norge avsies relativt mange forvaringsdommer med ganske lave tidsavgrensninger, og i nær halvparten av forvaringsdommene er tidsrammen satt til 6 år eller lavere. ${ }^{35}$ De fleste forvaringsdømte blir løslatt ved førstegangs begjæring om prøveløslatelse, men prøveløslatelsen finner sted noe tid etter oppnådd minstetid. ${ }^{36}$ I forhold til danske forvaringsdømte tilbringer norske forvaringsdømte kortere tid i forvaring (i fengsel). I Danmark har tiden til prøveutskrivelse fra forvaring økt fra 88 måneder i perioden 1990-94 til 175 måneder i perioden 20072011. ${ }^{37}$ Dette betyr at en forvaringsreaksjon i realiteten ikke trenger å være så inngripende i Norge som i Danmark.

I forhold til andre strafferettslige reaksjoner er det mest relevant at se hen til maksimal fengselsstraff som er 21 år (i noen tilfeller 30 år) i Norge og livstidsstraffen i Danmark. I Norge regnes forvaring som «lovens strengeste straff», altså den mest alvorlige straff man kan idømme når tidsrammen settes til 21 (30) år og minstetiden til $10(14 / 20)$ år, som f.eks. i Breivik-saken. ${ }^{38}$ I Danmark anser anklagemyndigheden fængsel i 14-16 år samt på livstid for at være strengere sanktioner end forvaring. ${ }^{39}$ En norsk flyvertinne ble i 2010 drept på Radisson Blu Scandinavia Hotel i København. De pårørende i Norge mente at straffen ikke var streng nok da gjerningsmannen ble dømt til 14 års fengsel istedenfor forvaring. ${ }^{40}$ I dansk kontekst ble gjerningspersonen derimot efter anklagemyndighedens vurdering straffet hardere enn om han hadde fătt forvaringsstraff. Denne vurdering må dog nok revideres i lyset af de nyeste oplysninger om den faktiske afsoningstid for forvaringsdømte. ${ }^{41}$

I Danmark vil den strengeste straffen være livstidsdom, og i svært alvorlige saker, også der tilbakefallsrisikoen anses for høy, velger retten å idømme livstidsdom selv om Retslægerådet har anbefalet forvaringsdom - se f.eks. Knudsen- 
saken. ${ }^{42}$ Dette er blitt tolket dithen at i Danmark bruges forvaring i sager, hvor der ikke er tale om den allerhøjeste straf, men der gerningspersonen udgør en særlig fare for samfundet, og der det på dette grunnlaget kan være nødvendig å holde ham fengslet lenger enn en tidsbestemt dom vil tilsi. ${ }^{43}$

I Grønland må forvaring uden tvivl anses som den strengeste foranstaltning, eftersom tidsbestemt anbringelse i anstalt ikke kan overstige 10 år. ${ }^{44}$ Der foreligger ingen opgørelse over de faktiske afsoningstider for grønlandske forvaringsdomme. Den 12.12.2014 var 32 grønlandsk dømte under afsoning af forvaring, og de havde på daværende tidspunkt i gennemsnit afsonet i 9 år og 8 måneder. ${ }^{45}$ Rent statistisk burde de i gennemsnit have afsonet halvdelen af tiden, hvilket fører til en antagelse om en samlet gennemsnitlig afsoningstid fra anholdelse til prøveløsladelse på godt 19 år. Beregningsmetoden er dog usikker, men at der er tale om meget langvarige forvaringstider, kan ikke betvivles.

\section{Fuldbyrdelse af forvaring}

Forvaring i Norge utholdes i fengsel, fortrinnsvis i forvaringsanstaltene Ila fengsel og Bredtveit fengsel (for kvinner) eller forvaringsavdelingen i Trondheim fengsel. Disse fengslene kategoriseres som fengsler med høyt sikkerhetsnivå. 5.1.2015 satt 87 forvaringsdømte i fengsel, hvorav 7 på åpne avdelinger/overgangsboliger. ${ }^{46}$ I Danmark kan forvaring i princippet afsones i ethvert fængsel, men det er dog den altovervejende hovedregel, at forvaringsdømte placeres i Anstalten ved Herstedvester. ${ }^{47}$ De grønlandske forvaringsdømte blir også anbrakt i Herstedvester, der de bor på en egen avdeling. I de seneste år er flere personer dog dømt til forvaring direkte i grønlandske (åbne) anstalter, og fra slutningen af 2018, hvor et lukket afsnit i en nybygget anstalt i Nuuk forventes taget i brug, vil ingen længere blive dømt til forvaring i anstalt i Danmark. De (danske og grønlandske) forvaringsdømte i Herstedvester er under dagligdagens fællesskabsaktiviteter blandet med fængselsdømte, og de er undergivet de samme regler. ${ }^{48}$

I Norge skal forvaring ha et annet innhold enn straff $i$ vanlig forstand, innholdet skal tilpasses de forvaringsdømtes særlige behov, og det skal være en tverrfaglig og tettere bemanning rundt de forvaringsdømte (det er tilsatt personer med sosialfaglig kompetanse). ${ }^{49}$ Behandling forestås av det offentlige helsevesen - såkalt importert tjeneste. En god del forvaringsdømte går også i samtaleterapi hos privatpraktiserende psykologer. Kjønnsdriftsdempende medisinsk behandling forekommer svært sjeldent, dette er en langt vanligere behandlingsform i Danmark. Tilsatte psykologer/psykiater i forvaringsanstaltene/-avdelingen behandler ikke, de foretar risikovurderinger av forvaringsdømte. Modsat i Norge og Grønland har danske fængsler ansat eget helsepersonale - såkalt selvforsyningsmodell - og i 
Herstedvester, som er det eneste fængsel med speciale i psykiatrisk og psykologisk behandling, er der fire psykiatriske overlæger, ti psykologer, syv sygeplejersker og to somatiske læger til - i nært tværfagligt samarbejde med anstaltens socialfaglige medarbejdere, fængselsbetjente og værkmestre - at varetage behandlings- og udredningsopgaver vedrørende anstaltens maksimalt 153 indsatte. ${ }^{50}$

Mens helsearbeidere i importmodellen er underlagt taushetsplikt om opplysninger som fremkommer i behandlingen, vil dette i praksis ikke være tilfellet på samme måte i selvforsyningsmodellen. Importmodellen legger godt til rette for opparbeidelse av tillit mellom behandler og pasient, men det kan oppstå en del vansker med utveksling av informasjon mellom helsepersonell, behandlere og fengselstilsatte. Dette kan f.eks. være problematisk i forhold til risikovurderinger av den forvaringsdømte. I selvforsyningsmodellen kan det oppstå vanskeligheter rundt tilliten mellom den forvarede og det psykiatriske og psykologfaglige helsepersonale, fordi den forvarede vet at informasjon som oppgis til helsespecialisten, som udgangspunkt også vil være tilgjengelig for fengselstilsatte som den forvarede vil mistenke vil kunne bli brukt som f.eks. argumenter mot utganger og prøveutskriving.

\section{Permisjoner og udslusning}

I Norge kan forvaringsdømte innvilges frigang (utgang fra fengselet til skole eller arbeid på dagtid) og permisjon samt overføres til fengsel med lavere sikkerhetsnivå etter at $2 / 3$ av minstetiden er sonet, og i den utstrekning sikkerhetsmessige hensyn og hensynet til den alminnelige rettsoppfatning ikke er til hinder for det. $^{51}$ Én av fire forvaringsdømte prøveløslates imidlertid uten å ha gjennomført permisjon, og flere som har gjennomført permisjoner, har kun hatt kortere permisjoner opptil ett døgns varighet. ${ }^{52}$

Det har vært vanskelig å få overført forvaringsdømte til åpne anstalter, men nå er Ullersmo fengsel avdeling Krogsrud opprettet som utslusningsanstalt for forvaringsdømte. ${ }^{53}$ Forvaringsdømte kan også overføres til overgangsbolig eller institusjon når en del av straffen er gjennomført. ${ }^{54}$ Kun ni forvaringsdømte er løslatt fra åpne fengsler/avdelinger, fra avdelinger med særskilte opplegg og oppfølging utover løslatelsestidspunktet (f.eks. rus), eller fra overgangsboliger. Dette betyr at de fleste forvaringsdømte løslates fra fengsler med høyt sikkerhetsnivå. ${ }^{55}$ Denne praksisen følger ikke intensjonene i straffegjennomføringsloven $\S 3$ og forvaringsforskriften $\S 3$ om gradvis tilbakeføring til samfunnet.

Tiden frem mot løslatelse for de forvaringsdømte i Danmark er en langvarig prosess med forsiktig lemping av sikkerhetsvilkårene. En prøveudskrivning i Danmark vil næsten altid forudsætte, at den forvarede forinden har gennemgået et 
udslusningsforløb, som typisk kan omfatte udgang, frigang, udstationering og eventuelt overførsel til åben fængselsafdeling eller såkaldt § 78-placering. ${ }^{56}$ Det er Direktoratet for Kriminalforsorgen, som efter indstilling fra vedkommende fængsel - og normalt efter høring af anklagemyndigheden - afgør sager om udgang, udstationering mv. ${ }^{57}$ Siden straffelovens $§ 72$ pålægger anklagemyndigheden at påse, at forvaring ikke opretholdes i længere tid og i videre omfang end nødvendigt, er anklagemyndigheden derfor ikke blot høringsmyndighed, men har en selvstændig interesse $\mathrm{i}$ at følge med i fuldbyrdelsens forløb. Anklagemyndigheden gennemgår årligt samtlige forvaringssager og indhenter i fornødent omfang oplysninger om status for afsoningsforløbet. Der er på denne baggrund et tæt samarbejde mellem Anstalten ved Herstedvester, Direktoratet for Kriminalforsorgen og anklagemyndigheden om lempelser i afsoningsforløbet for forvarede. ${ }^{58}$ Anklagemyndigheden har således en betydelig indflydelse på forløbet af udslusningen $i$ alle dens faser.

Vedrørende udgang (permission) er den forvaringsdømte omfattet af de samme regler, som gælder for fængselsdømte. ${ }^{59}$ For en forvaringsdømt indledes med enkeltstående ledsagede udgange, hvis antal og hyppighed gradvis forøges, og når det skønnes forsvarligt, kan der gives uledsaget udgang, først af nogle timers varighed og senere med overnatning. Slutstadiet for denne form for udgang indebærer ret til to døgns udgang (fra fredag eftermiddag til søndag aften) for hver tre ugers periode. Det er fængslets pligt at tage spørgsmålet om udgang op til overvejelse, når en forvaringsdømt har været anbragt i forvaring i 2 år, men igjen ser man en markant innstramming av praksis. Mens det i perioden 1990-94 gikk 3 år før den forvarede fikk ledsaget utgang og 3,5 år for uledsaget utgang, gikk det i perioden 2010-2011 i gjennomsnitt 3,5 år for ledsaget utgang og 11 år før uledsaget utgang. ${ }^{60}$

Åben afsoning sker kun yderst sjældent og i de fleste tilfælde kun til Herstedvesters egne åbne fængselsafdeling (Holsbjergvej). I stedet vil der i almindelighed ske udstationering til en af Kriminalforsorgens pensioner på «fængselsvilkår», hvilket indebærer, at den indsatte er frihedsberøvet i samme grad som under ophold (eventuelt med frigang) $i$ et fængsel, og det kan derfor være lidt misvisende at tale om «udstationering», som formelt er en form for udgang. ${ }^{61}$

I en senere fase kan fængselsvilkårene erstattes af «pensionsvilkår», som indebærer, at den forvarede skal overnatte på pensionen, men i øvrigt har han normalt inden for ganske frie rammer lov til at færdes ude i samfundet i fritiden. I nogle tilfælde - typisk som sidste led i et meget langvarigt forløb - vil der kunne ske udstationering til eget hjem. En sådan udstationering kan minde om en foranstaltningsændring (prøveudskrivning), men den foretrækkes i nogle tilfælde af 
myndighederne som en mere smidig ordning, fordi den kan iværksættes administrativt, og fordi den forvarede i tilfælde af vilkårsovertrædelse umiddelbart vil kunne tilbageføres administrativt til fængslet uden rettens medvirken. Tiden for påbegyndelse af utstationering har også økt fra i gjennomsnitt nesten 8 år i perioden 1990-94 til 10 år i perioden 2010-2011. ${ }^{62}$

For de grønlandske forvaringsdømte gælder nogenlunde samme regler og praksis som for de danske. ${ }^{63}$ Overførsel fra Herstedvester til åben anstalt (i Grønland) bruges dog hyppigere for de grønlandsk dømte, end det er tilfældet for danske forvaringsdømte. De Herstedvesteranbragte grønlændere har desuden særlige muligheder for en gang om året at få udgang til familiebesøg i Grønland eller omvendt at få betalt rejse for et familiemedlem i Grønland til besøg i Herstedvester. $^{64}$

\section{Prøveløslatelse/-udskriving og løslatelse/endelig ophævelse}

Når den forvaringsdømte begjærer seg løslatt på prøve i Norge kan kriminalomsorgen (regionalt nivå) beslutte løslatelsen hvis både kriminalomsorgen og påtalemyndigheten mener prøveløslatelse er sikkerhetsmessig forsvarlig. ${ }^{65}$ Hvis påtalemyndigheten og/eller kriminalomsorgen mener prøveløslatelse ikke er forsvarlig, skal påtalemyndigheten fremme saken for tingretten som avgjør den ved dom. Hvis den forvaringsdømte får avslag i retten, kan vedkommende ikke begjære seg løslatt igjen før ett år etter rettskraftig dom foreligger. ${ }^{66}$ De fleste forvaringsdømte løslattes av retten, og det skjer forholdsvis ofte at retten prøveløslater selv om påtalemyndigheten og/eller kriminalomsorgen går imot løslatelse. Dette er fordi retten ikke finner tilbakefallsfaren til ny alvorlig kriminalitet (særlig) nærliggende. ${ }^{67}$

I Danmark er det altid retten, som ved kendelse afgør, om foranstaltningen skal ændres i form af prøveudskrivning. Der er ikke noget lovkrav om, at en forvaret skal udskrives på prøve. I princippet kunne retten endeligt ophæve foranstaltningen uden forudgående prøveudskrivning, men dette forekommer ikke i praksis.

Efter tre års anbringelse i forvaring, skal fængslet årligt vurdere, om det er aktuelt at rejse sag om prøveudskrivning. ${ }^{68}$ Fængslets årlige vurdering skal baseres på en psykiatrisk udtalelse, og hvis fængslet anmoder anklagemyndigheden om at få sagen bragt for retten, skal der medfølge en psykiatrisk speciallægeerklæring. ${ }^{6}{ }^{6}$ Anklagemyndigheden skal også forelægge sagen for retten, hvis den forvarede selv, hans bistandsværge eller Kriminalforsorgens tilsynsafdeling anmoder om det. Tages en anmodning fra den dømte eller fra bistandsværgen ikke til følge, kan en ny anmodning ikke fremsættes, før der er forløbet et halvt år fra kendelsens afsigelse. ${ }^{70}$ 
De materielle betingelser for prøveudskrivning kan belyses ved følgende citat fra en Højesteretsdom fra 1980:

«Under hensyn til den særdeles alvorlige beskaffenhed af domfældtes kriminalitet og til de foreliggende oplysninger om hans personlige forhold, herunder retslægerådets erklæring (...), findes der ikke at være sikkert grundlag for at antage, at han ikke længere frembyder nærliggende fare for retssikkerheden. Det findes derfor ikke forsvarligt allerede nu at prøveudskrive domfældte, hvis frihedsberøvelse ikke har varet uforholdsmæssigt længe, og anklagemyndighedens påstand vil derfor være at tage til følge.»»

Den forvarede skal således prøveudskrives, når farligheden ikke længere vurderes som noerliggende. Der stilles strenge krav til grundlaget for en sådan vurdering («sikkert grundlag»). Med formuleringen: «Det findes derfor ikke forsvarligt allerede nu at prøveudskrive domfældte, hvis frihedsberøvelse ikke har varet uforholdsmæssigt længe» har Højesteret dog antydet, at prøveudskrivning på trods af en usikker farevurdering kan komme på tale, hvis frihedsberøvelsen har varet uforholdsmæssigt længe. Domstolene synes dog i praksis at være meget tilbageholdende med at lægge sådanne proportionalitetshensyn til grund for afgørelser om prøveudskrivning. ${ }^{72}$

Det er altså den samme vurderingen om nærliggende fare som legges til grunn for prøveløslatelse i Norge og Danmark. Til forskjell fra Danmark virker retten i Norge å ta proporsjonalitetshensyn i prøveløslatelsessaker, da den synes å stille større krav til bevisførsel jo nærmere tidpunktet for oppnådd tidsramme man kommer. ${ }^{73}$ Det som skal bevises i en rettssak om prøveløslatelse fra forvaring er at faren for gjentakelse fremdeles er nærliggende. ${ }^{74}$

I Norge må de forvaringsdømte ved prøveløslatelse innrette seg etter de vilkår som er satt. Brytes vilkårene kan den forvaringsdømte varetektsfengsles. Det er kun retten som kan gjeninnsette i forvaring.

I forbindelse med prøveudskrivning i Danmark fastsættes ingen prøvetid. Også i denne friere fase er tidsubestemtheden således absolut, og for visse forvarede, bl.a. sådanne, som har vilkår om kønsdriftdæmpende medicinsk behandling, kan prøveperioden blive langvarig. Der vil normalt være knyttet en række vilkår til prøveudskrivningen, herunder vilkår om, at der under nærmere angivne betingelser administrativt kan ske genindsættelse i fængslet. Det vil endvidere normalt være bestemt, at spørgsmålet om genindsættelsens opretholdelse i givet fald skal indbringes for retten senest en uge efter tilbageførslen.

Prøvetiden i Norge kan ikke strekke seg ut over tidsrammen for forvaringen, og en prøveløslatelse fra forvaring i Norge kan i prinsippet ikke vare i mer enn 5 
år. ${ }^{75}$ Retten har imidlertid gått utover denne tidsfristen for enkelte forvaringsdømte med diagnosen «lettere psykisk utviklingshemmet» som faller utenfor annet lovverk. For disse kan status som prøveløslatt synes å ha blitt ganske permanent, selv om lovverket ikke tillater dette. ${ }^{76}$ Per 5.1.2015 er 85 personer endelig løslatt fra forvaring ${ }^{77}$ og rettspraksis viser en grunnholdning i domstolen om at det skal være en progresjon mot løslatelse i forvaringssakene. ${ }^{78}$

I Danmark sker endelig udskrivning - dvs. ophævelse af foranstaltningen normalt, efter at den forvarede har været prøveudskrevet i en årrække, og dette forløb har været problemfrit. I sagen TfK 2000.531V blev foranstaltningen endelig ophævet ni år efter prøveudskrivningen. Der er dog også eksempler på, at retten har afvist endelig ophævelse af forvaringen efter tilsvarende langvarige prøveperioder, og i nogle tilfælde bliver foranstaltningen livsvarig. ${ }^{79}$

I Grønland er retstilstanden en dansk/norsk blanding. Som i Norge prøveløslades forvaringsdømte med en prøvetid på højst fem år. ${ }^{80}$ Efter udløbet af prøvetiden kan den dømte betragte sig som endligt løsladt fra sin forvaringsdom. Men som i Danmark er det altid retten, som afgør spørgsmålet om (prøve)løsladelse. Som i Danmark påhviler det anklagemyndigheden at påse, at en dom til forvaring ikke opretholdes i længere tid end nødvendigt. Anklagemyndigheden skal indbringe spørgsmålet om prøveløsladelse for retten senest 3 år efter dommen og derefter hvert andet år. ${ }^{81}$

\section{Avslutning}

Både Norge og Danmark har lange tradisjoner med å forvare lovbrytere på tidsubestemt tid for å beskytte samfunnet mot ny kriminalitet. Ved gjensidig påvirkning og under påvirkning av internasjonale diskurser ser vi klare paralleller i den historiske utviklingen. I dag ser vi at lovtekstene er ganske like i både Norge, Danmark og Grønland, der de samme kravene - kriminalitetskravet, farlighetskravet og nødvendighetskravet - settes som betingelser for idømmelse av forvaring. Mellom Norge og Danmark avspeiles likheten også i hvilke lovbrudd som medfører forvaring, med en slående likhet $\mathrm{i}$ den prosentvise fordelingen mellom lovbruddene. I begge land idømmes halvparten av forvaringsdommene for seksuallovbrudd, og i begge land er det også forholdsvis mange som idømmes forvaring for voldslovbrudd. Dette har nok en sammenheng med hvem vi forstår som «de farligste» i våre samfunn i dag, og hvem vi søker å ekskludere for å forhindre at de begår nye lovbrudd. ${ }^{82}$ Karakteravviket eller den psykiske afvigelse samt den «diagnostiske kultur» ${ }^{83}$ som omgir de forvaringsdømte, kan også betraktes som legitimering for å holde disse personene innesperret. 
Til tross for likheter i lovverk og rettspraksis i forhold til lovbrudd som gir forvaring, er det stor forskjell i omfanget $\mathrm{i}$ bruk av forvaring. Atskillig flere dømmes til forvaring i Norge enn i Danmark per år, og i Grønland tyder alt på, at der - i forhold til befolkningens størrelse - falder langt flere forvaringsdomme end i Norge og Danmark tilsammen. Tiden i forvaring er i gjennomsnitt kortere i Norge end i Danmark og Grønland. Disse oplysninger er interessante fordi det forteller oss hvor kontekstuelt farlighetskavet og nødvendighetskravet forstås. I Danmark og Grønland synes forvaring i dag å bli benyttet overfor lovbrytere som retten mener samfunnet virkelig trenger beskyttelse mot i lang tid fremover. I svært alvorlige saker hvor retten i Damark har et valg mellom forvaring og fengsel på livstid, ser vi at den kan velge å heller idømme livstid der det er behov for å uttrykke det pønale elementet. I Norge uttrykkes det pønale elementet i selve avsigelsen av forvaringsstraffen, som lovens strengeste straff, og i tidsavgrensningene (tidsrammen og minstetiden) - jo lengre de er, jo strengere oppfattes straffen. Det er meget mulig at ikke så mange ville blitt dømt til forvaring i Norge om man hadde hatt livstidsstraff, fordi retten i flere av de svært alvorlige sakene heller ville idømt livstid enn forvaring.

Paradoksalt nok virket det i Norge som det pønale elementet i tidsavgrensningene begrenser tidsubestemtheten i reaksjonen, og en rettssak om prøveløslatelse fra forvaring handler i prinsippet om berettigelsen av opprettholdelsen av forvaringen. Er ikke farlighetskravet og nødvendighetskravet oppfylt skal den forvaringsdømte løslates. Bevisbyrden ligger på påtalemyndigheten, og tvil om kravene er oppfylt skal komme den forvaringsdømte til gode. Slik virker det ikke å være i Danmark. Der taler man om forsvarlighet og beviser eller et godt grunnlag for at gjentakelsesfaren $i k k e$ lenger er nærliggende, altså det motsatte i forhold til Norge.

Den dramatiske økningen på lengden i forvaring og utslusingsforløpet i Danmark siden 1990 kan forstås som økt kriminalitetskontroll og et fokus på trygghet og sikkerhet for samfunnsborgerne. ${ }^{84}$ Anklagemyndighedens involvering i forvaringssakene i Danmark og Grønland med sitt fokus på rettshåndhevelsen/rettsfølelsen, selv om den efter loven har et ansvar for at forvaringen ikke opprettholdes lenger enn nødvendig, har nok vært en viktig faktor for økningene. I dette perspektivet blir borgernes og samfunnets rettssikkerhet det sentrale. I Norge er tidsavgrensningene også viktig for den forvaringsdømtes rettssikkerhet. Minstetiden sikrer at den forvaringsdømte selv får en anledning til å prøve berettigelsen av forvaringen, og retten må ta stilling til opprettholdelse av forvaringen ved oppnådd tidsramme. Maksimal tid for prøveløslatelse skal også sikre at prøveløslatelsen ikke varer for lenge, og for å unngå det juridiske problemet at man 
bryter femårsregelen ønsker Riksadvokaten i Norge nå en avklaring på om prøveløslatelse kan regnes som straffegjennomføring. ${ }^{85}$ I så fall vil man løse et juridisk problem, for tidsrammen kan forlenges i det uendelige, men det oppstår et etisk problem i forhold til hvor lenge man kan holde mennesker med utviklingshemming under straffegjennomføring.

Kriminalomsorgsfaglig gir det god mening at løsne kontrollen med den dømte ganske gradvist. I så måte har man i Danmark og Grønland et atskillig mer tilpasset og fleksibelt system enn man har i Norge. Den totale tidsubestemtheten i dansk ret gir rom og tid til å teste ut og observere hvordan den forvaringsdømte mestrer et stadig mer friere regime. At helsetjenesten, navnlig den psykologiske og psykiatriske virksomhed - varetages på så vidt forskellig vis, kan også ha betydning for fuldbyrdelsen af forvaring og for vurderingerne, som lægges til grund for tilbagefaldsrisikoen ved overvejelser om prøveløslatelse/-udskrivning.

Vi finner altså et mer praksisrettet, fleksibelt og dynamisk forvaringssystem i Danmark og Grønland enn i Norge. I Norge er forvaringssystemet mer regelstyrt og prinsipielt, men det synes å sikre ivaretakelse av den forvaringsdømtes interesser i større grad enn i Danmark og Grønland. Samtidig er det norske systemet mer robust i forhold til å bli påvirket av det som til enhver tid er den rådende rettsoppfatning/rettsfølelse, mens det danske og grønlandske lettere kan tilpasses denne. Ut fra hvilken fortolkningsramme man legger til grunn kan man derfor finne både fordeler og ulemper med de ulike systemene.

\section{Noter}

1. Berit Johnsen, forskningsleder Kriminalomsorgens utdanningssenter (KRUS), postboks 6138 Etterstad, 0602 Oslo, berit.johnsen@krus.no

Hans Jørgen Engbo, Direktør for Kriminalforsorgen i Grønland, Aqqusinersuaq 4, 2 sal tv., Postboks 369, 3900 Nuuk, HJE@kriminalforsorgen.gl

2. Vi har ladt vore bidrag til teksten indgå på vore respektive originalsprog. Blandingen af norsk og dansk gjør, efter vores opfattelse, teksten likevel forståelig.

3. NOU 1974: 17; NOU 1990: 5.

4. Nelken, 2009.

5. Christie, 2000.

6. Straffeloven (strl.) $\S \S 39,39$ a-g. De to andre særreaksjonene er tvungent psykisk helsevern og tvungen omsorg for lovbrytere som blir funnet utilregnelige pga. henholdsvis psykose eller bevisstløshet i gjerningsøyeblikket, eller fordi de blir ansett for å være psykisk utviklingshemmet i høy grad (strl. § 44).

7. NOU 1974: 17.

8. NOU 1983: 57 s. 198; Rt. 1983-1043.

9. NOU 1990: 5.

10. Ot.prp. nr. 87 (1993-94); Ot.prp. nr. 46 (2000-2001). 
11. Straffeloven, lov 20.5.2005, kap. $7 \S$ 40-47 (ikke i kraft); Ot.prp. nr. 90 (2003-2004) s. 274.

12. Lov nr. 320 af 13.06 .1973 .

13. Straffelovens $\S 70$, som den var formuleret før 1973-reformen (oprindelig $\S 17$, stk. 2).

14. Straffelovens (dagældende) $\S \S 65-66$.

15. Kriminallovens $\S 102$, stk. 2, jf. ændringslov nr. 292 af 06.08.1978.

16. Kriminallovens $\S 161$.

17. Johnsen, 2006.

18. NOU 1974: 17 s. 82.

19. Waaben, 2001; Toftegaard Nielsen, 2002.

20. Lovforslag nr. 12/1996-97, bemærkninger til nr. 8 og 9.

21. Strl. $39 \mathrm{c} \mathrm{nr} .10$.

22. Strl. § 39 d; Straffeprosessloven (strpl.) § 165; Johnsen, 2013.

23. NOU: 19905 s. 110; Rapport 18. mai 2006; Westin, 2011.

24. Straffelovrådets betænkning nr. 667/1972 s. 76f.; Lovforslag nr. 128/1972-73, afsnit A 2.

25. Kriminallovens $\S 156, \S 161$, stk. 2.

26. Strl. § 39 e. Etter lov 9. januar 2015 (i kraft samme dag) er det foretatt endringer av tidsrammen til utover 21 år og minstetiden til utover 10 år.

27. Ibid.

28. NOU 1990: 5 s. 118; NOU 1974: 17 s. 97.

29. Johnsen, 2011.

30. Straffelovens $\S 72$; Kriminallovens $\S 162$, stk. 4.

31. Kriminalomsorgens registrerings- og saksbehandlingssystem (Kompis).

32. Forvaring og udstrokningen heraf.

33. Selv om oppfølgingsperiodene er noe forskjellig i Norge og Danmark mener vi sammenligningen gir et godt bilde fordi fordelingen mellom lovbruddene er forholdsvis stabil i begge land i løpet av periodene.

34. Johnsen, 2013.

35. Kompis.

36. Johnsen, 2013.

37. Forvaring og utstrcekningen heraf.

38. TOSLO-2011-188627-24 - RG-2012-1153.

39. Anklagemyndighedens Årsberetning 2003-04, s. 98 f. Anklagemyndighedens vurdering er dog baseret på ældre opgørelser over den faktiske afsoningstid for forvaringsdømte.

40. F.eks. Dagbladet nettutgave 24.02.11.

41. Forvaring og udstrakningen heraf.

42. John Knudsen blev ved Retten i Sønderborg den 22. september 2010 idømt livstids fængsel. Retslægerådet havde anbefalet forvaring. Se http://da.wikipedia.org/wiki/John_Knudsen.

43. Jydske Vestkysten 23.09.10.

44. Kriminallovens $\S 147$, stk. 1.

45. Kilde: Kriminalforsorgen i Grønland, Hovedkontoret.

46. Kompis.

47. Straffuldbyrdelseslovens $\S 105$. 
48. Ibid.

49. FOR-2004-03-05-481 §3.

50. Opgjort ultimo februar 2012.

51. Straffegjennomføringsloven (strgjfl). § 2; FOR-2004-03-05-481 $\S 9,11,12$.

52. Johnsen, 2013.

53. Prop $1 \mathrm{~S}(2014-2015)$.

54. Strgjfl. § 15; FOR-2004-03-05-481 § 10 .

55. Johnsen, 2013.

56. Straffuldbyrdelseslovens $\S 78$.

57. Udgangsbekendtgørelsens $\S 19$.

58. Anklagemyndighedens Årsberetning 2003-04, s. 109 f.

59. Straffuldbyrdelseslovens $\S 105$, jf. $\S \S 46-50$; udgangsbekendtgørelsen.

60. Forvaring og udstrakningen heraf.

61. Udgangsbekendtgørelsens kap. 11.

62. Forvaring og udstrcekningen heraf.

63. Bekendtgjørelse nr. 1168 af 07.12.2009 om forvaring, der fuldbyrdes i Grønland.

64. Justitsministeriets cirkulære nr. 9081 af 17.03.2011.

65. Strl. § $39 \mathrm{f}$.

66. Ibid.

67. Rt. 2014-934; Rt. 2014-946; Johnsen, 2013.

68. Prøveudskrivningsbekendtgørelsens $\S 2$.

69. Ibid., $\S 3$.

70. Straffelovens $\S 72$.

71. UfR $1980.877 \mathrm{H}$.

72. Se fx UfR 2000.1419 V. Til belysning af spørgsmålet om proportionalitet kan det om den konkrete sag oplyses, at der i Højesteret var dissens for udmåling af fængsel i 3 år i stedet for forvaring, og at den dømte nu havde været frihedsberøvet i 10 år, men retten henviste til, at det ikke i straffelovens $§ 72$ er bestemt - og det fremgår ikke af bestemmelsens forarbejder - at proportionalitetshensyn skal være afgørende for, om foranstaltninger efter straffelovens $\S 70$ om forvaring, skal ændres eller ophæves. Oplyst i Anklagemyndighedens Årsberetning 2003-04, s. 119. Se tilsvarende TfK2000.349, som blev stadfæstet ved Højesterets anke- og kæremålsudvalgs kendelse af 13. december 2000 (sag 300/2000).

73. Johnsen, 2013.

74. Rt. 2014-934; Rt. 2014-946.

75. Strl. $\S 39$ f; FOR-2004-03-05-481 § 15.

76. Johnsen, 2012.

77. Kompis.

78. Johnsen, 2013.

79. Se fx Højesterets kendelse af 2. november 2005 (sag nr. 193/2005) jf. Anklagemyndighedens Årsberetning 2003-04 s. 122.

80. Kriminallovens $\S 162$.

81. Ibid., stk 4.

82. Garland, 2001.

83. Løchen 1996; Midtlyng, 2014. 
84. Garland, 2001.

85. Brev fra Riksadvokaten til Justisdepartementet 15.7.2011.

\section{Referanser}

Anklagemyndighedens Årsberetning 2003-04.

Brev fra Riksadvokaten til Justisdepartementet 15.7.2011.

Christie, N. (2000) Kriminalitetskontroll som industri: Mot GULAG, vestlig type. Oslo, Universitetsforlaget, 3. utg.

Dagbladet nettutgave 24.02.11.

Forvaring og udstrcekningen heraf: En gennemgang af forvaringssager $i$ Anstalten ved Herstedvester for perioden 1. januar 1990 til 31. december 2011. Anstalten ved Herstedvester.

Garland, D. (2001) The Culture of Control. Crime and Social Order in Contemporary Society. Oxford, Oxford University Press.

http://da.wikipedia.org/wiki/John_Knudsen

Johnsen, B. (2006) Forvaring - et barn av sin tid? Materialisten, 4.

Johnsen, B. (2011) Forvaring - fra særreaksjon og «straff» til lovens strengeste straff: Ett skritt frem eller ett tilbake? Nordisk Tidsskrift for Kriminalvidenskap, 1.

Johnsen, B. (2012) Prøveløslatelse fra forvaring med vilkår om opphold i institusjon eller kommunal boenhet utover ettårsfristen - ikke bare noen, men mange problemstillinger. Kritisk Juss, 1.

Johnsen, B. (2013) Elleve år med forvaring: Løslatelser - praksis og rettspraksis - og tilbakefall. Lov og rett, 6.

Jydske Vestkysten 23.09.10.

Lovforslag nr. 128/1972-73. Almindelige bemarkninger.

Lovforslag nr. 12/1996-97. Betcenkning over Forslag til lov om andring af straffeloven, retsplejeloven og lov om udlagning af åndssvageforsorgen og den øvrige sarforsorg m.v. (Samfundstjeneste og forstoerket indsats mod seksualforbrydelser m.v.).

Løchen, Y. (1996) Idealer og realiteter $i$ et psykiatrisk sykehus. Oslo, Universitetsforlaget, 3. utg.

Midtlyng, G. (2014) Samfunnsvern? En studie av rettens vurdering i saker om løslatelse fra forvaring. Masteroppgave, Institutt for kriminologi og rettssosiologi, Det juridiske fakultet, Universitetet i Oslo.

Nelken, D. (2009) Comparative Criminal Justice: Beyond Ethnocentrism and Relativism. European Journal of Criminology, 4.

NOU 1974: 17 Strafferettslig utilregnelighet og strafferettslige scerreaksjoner.

NOU 1983: 57 Straffelovgivning under omforming.

NOU 1990: 5 Strafferettslige utilregnelighetsregler og sarreaksjoner.

Ot.prp. nr. 87 (1993-94) Om lov om endringer $i$ straffeloven $m v$ (strafferettslige utilregnelighetsregler og sarreaksjoner).

Ot.prp. nr. 46 (2000-2001) Om lov om endringer $i$ straffeloven og $i$ enkelte andre lover (endring og ikraftsetting av strafferettslige utilregnelighetsregler og scerreaksjoner samt endringer $i$ straffeloven $\$ \$ 238$ og 239).

Ot.prp. nr. 90 (2003-2004) Om lov om straff (straffeloven).

Prop 1 S (2014-2015) Justis- og beredskapsdepartementet. 
Rapport fra utredningsgruppe oppnevnt av Justis- og politidepartementet 18. mai 2006 Etterkontroll av reglene om strafferettslig utilregnelighet, strafferettslige sarreaksjoner og forvaring. Justis- og politidepartementet.

Straffelovrådets betænkning nr. 667/1972 om de strafferetlige særforanstaltninger.

Toftegaard Nilsen, G. (2002) Strafferet 2, Sanktionerne. København, Christian Ejlers' Forlag.

Westin, B.C. (2011) Forvaring på Ila 2002-2010: En oversikt over innholdet i forvaringen på Ila samt trekk ved forvaringsdømte. Bærum, Ila fengsel og forvaringsanstalt.

Waaben, K. (2001) Strafferettens almindelige del II, Sanktionslaeren. København, Thomson GadJura, 5. utg.

Norske rettskilder

Almindelig borgerlig Straffelov (straffeloven, strl.) 22.5.1902.

Lov om rettergang i straffesaker (straffeprosessloven, strpl.) 22.5.1981.

Lov om gjennomføring av straff mv. (straffegjennomføringsloven, strgjfl.) 18.5.2001.

Straffeloven, lov 20.5.2005 om straff (ikke i kraft).

FOR-2004-03-05-481. Forskrift om gjennomføring av særreaksjonen forvaring (forvaringsforskriften).

\section{Danske retskilder}

Lov nr. 126 af 15.04.1930 Borgerlig Straffelov med senere ændringer, jf. lovbekendtgørelse nr. 871 af 04.07.2014 (straffeloven).

Lov nr. 432 af 31.052000 om fuldbyrdelse af straf mv. med senere ændringer, jf. lovbekendtgørelse nr. 435 af 15.05.2012 (straffuldbyrdelsesloven).

Bekendtgørelse af 29.03.2012 om udgang til indsatte, der udstår fængselsstraf eller forvaring i kriminalforsorgens institutioner (udgangsbekendtgørelsen).

Bekendtgørelse nr. 355 af 12.04.2012 om behandlingen af sager om prøveudskrivning af forvaringsdømte (prøveudskrivningsbekendtgørelsen).

Justitsministeriets cirkulære nr. 9081 af 17.03.2011 om behandlingen af personer, der er anbragt i Anstalten ved Herstedvester i henhold til den grønlandske kriminallov.

Grønlandske retskilder

Lov nr. 55 af 05.03.1954 Kriminallov for Grønland (Kriminalloven 1954).

Lov nr. 306 af 30.04.2008 Kriminallov for Grønland (Kriminalloven).

Bekendtgørelse nr. 1168 af 07.12.2009 om forvaring, der fuldbyrdes i Grønland.

Norske domsavgjørelser

Rt. 1983-1043.

Rt. 2014-934.

Rt. 2014-946.

TOSLO-2011-188627-24 - RG-2012-1153.

Danske retsafgørelser

UfR $1980.877 \mathrm{H}$.

UfR 2000.1419V. 
TfK2000.349.

TfK 2000.531V.

Højesterets kendelse af 2. november 2005 (sag nr. 193/2005).

Højesterets anke- og kæremålsudvalgs kendelse af 13. december 2000 (sag 300/2000). 